University of Nebraska - Lincoln

DigitalCommons@University of Nebraska - Lincoln

Faculty Publications, Classics and Religious

Studies Department

January 2005

\title{
Christian Aramaism: The Birth and Growth of Aramaic Scholarship in the Sixteenth Century
}

Stephen G. Burnett

University of Nebraska - Lincoln, sburnett1@unl.edu

Follow this and additional works at: https://digitalcommons.unl.edu/classicsfacpub

Part of the Classics Commons

Burnett, Stephen G., "Christian Aramaism: The Birth and Growth of Aramaic Scholarship in the Sixteenth Century" (2005). Faculty Publications, Classics and Religious Studies Department. 48.

https://digitalcommons.unl.edu/classicsfacpub/48

This Article is brought to you for free and open access by the Classics and Religious Studies at DigitalCommons@University of Nebraska - Lincoln. It has been accepted for inclusion in Faculty Publications, Classics and Religious Studies Department by an authorized administrator of DigitalCommons@University of Nebraska - Lincoln. 


\title{
Seeking Out \\ the Wisdom of the Ancients
}

\author{
Essays Offered to Honor \\ M ichael V. Fox
}

on the Occasion of His Sixty-Fifth Birthday

\author{
Edited by \\ RONALD L. TROXEL \\ KELVIN G. FRIEBEL \\ and \\ DENNIS R. MAGARY
}

Winona Lake, Indiana

EISENBRAUNS

2005 


\title{
Christian Aramaism: The Birth and Growth of Aramaic Scholarship in the Sixteenth Century
}

\author{
STEPHEN G. BURNETT \\ University of Nebraska-Lincoln
}

Since the mid-nineteenth century, Jewish historians have marveled at the vigorous growth and vitality of Christian Hebrew scholarship in early modern Europe. Ludwig Geiger and Moritz Steinschneider chronicled parts of this astonishing and unexpected phenomenon. ${ }^{1}$ During the past 50 years, Karlheinz Burmeister, R. Gerald Hobbs, Bernard Roussel, Gerard Well, and Jerome Friedman have provided biographies and analyses of the achievements of some of the most important Christian and Jewish scholars who made this possible. ${ }^{2}$ In my own research I have sought to quantify the growth of Hebrew learning among Christians through analyzing the Christian Hebrew printing industry as it developed. To honor my teacher Michael V. Fox, however, I wish to write, not on Christian Hebraism, but on the growth of Aramaic learning among Christians during the fifteenth and sixteenth centuries. ${ }^{3}$ The Christian study of Aramaic literature illustrates even more sharply than Christian Hebraism the religious and philological barriers that hindered the study of Jewish literature by non-Jews and the often-surprising ways that these barriers were surmounted. ${ }^{4}$

1. Ludwig Geiger, Das Studium der Hebrdischen Sprache in Deutschland vom Ende des XV bis zur Mitte des XVIJahrhunderts (Breslau: Schletter'sche Buchhandlung, 1870); and Moritz Steinschneider, Christliche Hebmisten: Nachrichten uber mehr als 400 Gelehrte, welche uber nachbiblisches Hebrdisch geschrieben haben (Hildesheim: Gerstenberg, 1973).

2. Stephen G. Burnett, "Christian Hebrew Printing in the Sixteenth Century: Printers, Humanism, and the Impact of the Reformation," Helmantica 51/154 (April 2000) 13-42.

3. I will not discuss developments in the study of either Biblical Aramaic, which has always been taught with Biblical Hebrew, or Syriac, which was encouraged primarily by contact with eastern Christians rather than Jews. See Werner Strothmann, Anfdnge der Syrischen Studien (Wiesbaden: Harrassowitz, 1971).

4. I chose this topic, in part, because postbiblical Aramaic was the most difficult class that I had with Michael. I hope that my most-recent foray into Aramaic scholarship will please him more. 
Postbiblical A ramaic literature was forbidding to the would-be Christian reader for a number of reasons. First, it was fundamentally J ewish literature. Christians could justify the study of Biblical Hebrew and the Hebrew Bible text because the Hebrew Bible (Old Testament) was a part of their own biblical canon. Biblical humanists and theologians, Protestant and Catholics alike, could point to St. Jerome, Nicholas of Lyra, Paul of Burgos, and other predecessors in the Christian study of Hebrew. J ewish A ramaic literature, however, included the Targums, the Talmud, and the Zohar, all of which had been written by J ews for J ews after the close of the New Testament canon. A ssuming Christian scholars could overcome the religious barrier, very few of them were able to overcome the lack of L atin-language A ramaic grammars and lexicons and the rarity of the texts themselves. While the patronage of secular or church officials could and did enable Christian A ramaists to make impressive strides, the assistance of J ewish converts and professing J ews was essential for the growth of this new field. By 1600, A ramaic study had found a home within the world of Christian learning, as attested both by the number of A ramaic-related titles printed and also by the $A$ ramaic library holdings of both individual scholars and universities.

Why should Christians devote time to reading Jewish A ramaic books? During the fourteenth and fifteenth centuries, such Christian A ramaic learning as existed was largely devoted to anti-J ewish polemics or proselytizing. The Christians scholars who pursued it, many of them Jewish converts, combed the Talmud, kabbalistic literature, and the Targums for passages that appeared to support Christian doctrines and perspectives. ${ }^{5}$ The theological need to use J ewish A ramaic texts for Christian polemics was sufficient motivation for a few scholars to devote themselves to the study of A ramaic, but only a few. Only when Christian scholars came to believe that these texts could benefit Christian theology and academic life in a constructive way by providing information useful to Christians would A ramaic literature find a larger niche within the Christian world of learning. ${ }^{6}$

5. Gershom Scholem, "Beginnings of Christian Kabbalah," in The Christian Kabbalah: J ewish Mystical Books and Their Christian Interpreters (ed. Joseph Dan; Cambridge: Harvard College L ibrary, 1997) 27-30; David Ruderman, "I talian Renaissance and J ewish Thought," in Renaissance Humanism: Foundations, Forms, and Legacy, vol. 1: Humanism in Italy (ed. Albert Rabiljr.; Philadel phia: U niversity of Pennsylvania Press, 1988) 395-96; andjeremy Cohen, Friars and the ews (Ithaca: Cornell University Press, 1982) 131-56.

6. The prime example of a book that $\mathrm{C}$ hristian scholars came to accept as useful for their purposes was M aimonides' Guide to the Perplexed. See Jeremy Cohen, Living Letters of the Law: Ideas of the Jew in Medieval Christianity (Berkeley: University of California Press, 1999) 382-83. 
For Christian scholars, finding a satisfactory motive for studying A ramaic literature was simpler for some genres than for others. By the late fifteenth century, the Christian case for Targumic study had long been clear. Not only had polemicists such as Raymundo $M$ arti found the Targums useful, but so had biblical commentators. Nicholas of Lyra, for example, discovered that the Targums contained much information that Christian exegetes could use, not only to refute Jewish interpretations of passages, but also to bolster Christian ones. ${ }^{7}$

While other Christian scholars, some of them J ewish converts, had put kabbalistic literature to use in the cause of Christian missionizing by the early fifteenth century, it was Count Giovanni Pico della M irandola (1463-94) who first saw another, quite different benefit for kabbalistic study. He believed and taught that "non-biblical J ewish sources were meaningful and relevant to Christianity itself." ${ }^{8}$ Pico's own understanding of Kabbalah was shaped both through the Latin translations of the sources and through his own Platonic and Pythagorean philosophical framework. Although Pico himself did not read the Zohar, either in translation or in the original, he justified its study by Christians. ${ }^{9}$

The most difficult A ramaic book to justify for Christian study was the Talmud. Through the work of Peter the Venerable of Cluny (1094-1156), the idea that the Talmud was a "heretical" work had entered Christian theological tradition. The earlier medieval theological understanding of Judaism (and the predominant one throughout the Middle Ages) was that Jews had functioned as witnesses to the truth of Christianity by continuing to live according to the laws of the Pentateuch, serving as "living letters" of the biblical text. Jeremy Cohen has argued that Peter and other later theologians believed that the Talmud was "heretical" because it represented a new law whose authority among Jews was greater than that of the Bible. Peter also understood the Talmud to be "sinister, insane, blasphemous, diabolical J ewish doctrine." ${ }^{10}$ Christian authorities justified Talmud-burnings in the fourteenth century because the work contained "blasphemies, errors, curses, and lies." ${ }^{11} Y$ et, despite the Talmud's

7. Frans van Liere, "The Literal Sense of the Books of Samuel and Kings: From Andrew of St Victor to Nicholas of Lyra," in Nicholas of Lyra: The Senses of Scripture (ed. Philip D. W K rey and Lesley Smith; Studies in the History of Christian Thought 90; Leiden: B rill, 2000) 77-81.

8. J oseph Dan, "The Kabbalah of J ohannes Reuchlin and Its Historical Significance," in The Christian Kabbalah: J ewish Mystical Books and Their Christian Interpreters (ed. Joseph Dan; Cambridge: Harvard College Library, 1997) 56.

9. Chaim Wirszubski, Pico della Mirandola's Encounter with) ewish Mysticism (Cambridge: Harvard University Press, 1989) 20-21, 187.

10. Cohen, Living Letters, 260-64.

11. Ibid., 330. 
evil reputation -within Christian scholarship, by the early sixteenth century even Talmudic study could be justified on humanist grounds.

Johannes Reuchlin is best known as the author of the first Latin-language Hebrew grammar and for his devotion to the K abbalah. But Reuchlin also was the author of an Opinion about the Books of the Jews written for the imperial commission that was summoned to study Pfefferkorn's proposal to confiscate J ewish books. ${ }^{12}$ When he discussed the Talmud, Reuchlin asserted that it contained information valuable to the most important university-level disciplines (that is, theology, law, and medicine). He wrote:

For it contains many good medical prescriptions and information about plants and roots, as well as good legal verdicts collected from all over the world by experienced Jews. And in theology the Talmud offers in many passages arguments against the wrong faith. This can be seen from the bishop of Burgos's books concerning the Bible, which he has -written in a praisew orthy and Christian manner and in the Scrutinium Scripturarum, in which he clearly protects our faith on the basis of the Talmud.

Indeed, Reuchlin found no fewer than 50 passages in which Paul of Burgos quoted Talmudic passages in the latter book. ${ }^{13}$ Reuchlin's argument was less important for its immediate effect on imperial policy than as an important legal opinion and precedent that established a rationale for allowing Christians to use- and to print- the Talmud. The two opinions submitted by the theology faculty of Basel and A mbrosius Froben to defend the propriety of printing the Basel Talmud in late 1578 or early 1579 reflect and note Reuchlin's arguments. ${ }^{14}$

A round 1635, J ohannes Buxtorf the $Y$ ounger wrote a letter with advice on how to begin the study of postbiblical A ramaic. The student, he wrote, must first attain a good knowledge of A ramaic dialects, consult a variety of study aids, and above all, purchase any L atin translations of these books, because by comparing the original text with the Latin, the student would be able to make rapid progress. ${ }^{15}$ In the days of Pico and Reuchlin, almost none of these tools was

12. The original opinion was submitted on 0 ctober 6,1510 , and was subsequently printed with annotations in R euchlin's book Augenspiegel (Tiibingen, 1511), as a part of his pamphlet war with Pfefferkorn. Erika Rummel, The Case against J ohann Reuchlin: Religious and Social Controversy in Sixteenth-Century Germany (Toronto: University of Toronto Press, 2002) 88.

13. Ibid., 92.

14. Stephen G. B urnett, "The Regulation of Hebrew Printing in Germany, 1555-1630: Confessional Politics and the Limits of Jewish Toleration," in Infinite Boundaries: Order, Disorder, and Reorder in Early Modern German Culture (ed. M. R.einhart and T. R^obisheaux; Kirksville, M o: Sixteenth Century J ournal Publishers, 1998) 339-40.

15. Peter T. van Rooden, Theology, Biblical Scholarship and Rabbinical Studies in the Seventeenth Century: Constantijn L'E mpereur (1591-1648), Professor of Hebrew and Theology at Leiden 
available to Christians. The creation of a philological apparatus of A ramaic grammars, dictionaries, and bilingual text editions (some with annotations) was one of the greatest achievements of sixteenth-century Christian A ramaists.

The very first A ramaic grammar composed in Latin for Christian students was written by Sebastian M iinster, a professor at the University of Heidelberg, and was printed in 1527. M iinster learned Hebrew from Conrad Pellican, his superior in the Franciscan order, and $M$ atthaeus A drianus, a Jewish convert from Spain who taught a number of the most important Protestant Hebraists of the early sixteenth century. ${ }^{16}$ M ost of his A ramaic education, however, involved personal study, with occasional help from professing J ews. ${ }^{17} \mathrm{M}$ iinster's grammar was intended to help students learn not only A ramaic but also enough medieval Hebrew (including abbreviations) to read Jewish biblical c ommentaries.

M iinster's pioneering grammatical work would find few emulators, at least during the sixteenth century. Only seven authors composed A ramaic grammars. Four of these were at least nominally Catholic (Theseus A mbrosius, George A mira, Angel Caninius, and J ean M ercier), and three were Protestant (Sebastian M iinster, Cornelius B ertram, and Immanuel Tremellius). Two of these authors, A mira and A mbrosius, lived and worked in Italy, while the other four lived and worked in the French-speaking world. Both Caninius and M ercier taught Hebrew at the College Roy ale of the University of Paris, the former during the 1550s, and the latter from 1547 to 1570, while B ertram was one of M ercier's students. B ertram taught Hebrew at the A cademy of Geneva from 1567 to 1586, and Tremellius taught Hebrew at the University of Heidelberg from 1561 to 1575, though like B ertram he had his grammar printed in Geneva. M ercier and his colleagues at the College Royale played a critical role in providing both grammatical helps and annotated Aramaic texts for other would-be A ramaic scholars.

(trans. J. C. Grayson; Studies in the History of L eiden University 6; L eiden: B rill, 1989) 119.

16. Stephen G. Burnett, "Reassessing the 'Basel-Wittenberg Conflict': Dimensions of the Reformation-Era Discussion of Hebrew Scholarship," in Hebraica Veritas? Christian Hebraists and the Study of J udaism in Early Modern Europe (ed. Allison P. Coudert and J effrey S. Shoulson; Philadelphia: U niversity of Pennsylvania Press, 2004) 183.

17. A ccording to Prijs, M iinster's usual way of indicating J ewish help in his works was to use the formula a docto quodam ludaeo (M iinster, Chaldaica G rammatica, f. a3r; J Joseph Prijs, Die Easier Hebrdischen Drucke (1492-1866) [ed. Bernhard Prijs; OIten and Freiburg i. Br.: U rs Graf, 1964] 43). Self-study was frequently the only way for Christians to learn Hebrew in the early sixteenth century. See Karl Heinz Burmeister, "Johannes Campensis und Sebastian M iinster: Ihre Stellung inder Geschichte der Hebraischen Sprachstudien," ETL 46 (1970) 443-47. 
Providing serviceable A ramaic lexicons for Christian students proved to be a far greater challenge than grammars. A part from the Hebrew-A ramaic dictionary of A Ifonso de Zamora in vol. 6 of the Complutensian Polyglot Bible (1514-17), all scholarly attempts to write an A ramaic dictionary would be based to some degree on Nathan ben $\mathrm{Y}$ ehieF s Sefer Aruk (ca. 1100). ${ }^{18} \mathrm{~N}$ athan ben $Y$ ehiel wrote his lexicon for advanced students of the Talmud, the Targums, and the M idrash and focused his attention on explaining foreign and difficult words while leaving out more common ones. Moreover, he did not organize his dictionary according to the principle of trilateral roots (which he either did not accept or was perhaps unaware of) but used an alphabetical order. ${ }^{19}$ W hile some Christian Hebraists had the ability to use Sefer Aruk as it was written, most needed a much smaller, Latin summary of it.

J ewish author Elias L evita wrote the first A ramaic dictionary specifically intended for Christian readers at the request of his patron, Cardinal V iterbo. V iterbo may have learned the rudiments of $\mathrm{H}$ ebrew as early as his stay in Florence during 1497, and throughout his career he was keenly interested in kabbalistic learning and the Targums, as well as in oriental studies generally. ${ }^{20} \mathrm{He}$ hired Elias Levita to serve as his personal tutor in Hebrew and A ramaic from 1515 until 1527. At Viterbo's initiative Levita took on the unenviable task of compiling the first Targumic dictionary, combing through Nathan ben $\mathrm{Y}$ ehiel's Sefer Aruk for information, and providing further references to Latin and Greek loanwords in the Targums. Levita organized his work alphabetically and used the trilateral root as his organizing principle. ${ }^{21}$ Levita was forced to leave Rome and move to $V$ enice because of the sack of Rome in 1527, but V iterbo provided further financial support for Levita, which allowed him to complete the dictionary between 1528 and 1530. Levita's work, entitled M eturgaman, or "Interpreter," was finally printed by Paul Fagius in Isny during $1541 .{ }^{22}$

In 1523, Santes Pagninus wrote Enchiridion expositionis vocabulorum Haruch, the first A ramaic dictionary actually to appear in print. Pagninus learned Hebrew in Florence from Clemente A braham, a Spanish-J ewish convert. ${ }^{23} \mathrm{He}$

18. Zamora, Vocabularium Hebaicum, in Biblio Polyglotta, vol. 6, f. ir-clxxii r.

19. Shimeon Brisman, History and Guide to J udaic Dictionaries and Concordances (vol. 3/1; Hpboken, NJ.: KTAV, 2000) 16.

20. Francis X. Martin, Friar, Reformer and Renaissance Scholar: Life and Work of Giles of Viterbo 1469-1532 (The A ugustinian Series 18; Villanova, Pa.: A ugustinian Press) 163.

21. Ibid., 169-71; and Gerard E. Weil, Elie Levita Humaniste et Massorete (1469-1549) (Studia Post-Biblica 7; Leiden: B rill, 1963) 116.

22. Ibid., 115-17. On the philological character of the work, see pp. 271-79.

23. Santiago Garcia-Jalon de la Lama, Lagramdtica hebrea en Europa en el siglo XVI. Guiaa de lectura de las obras impresas (Salamanca: Publicaciones Universidad Pontifica, 1998) 115. 
served as a professor of Hebrew in Rome while Leo $X$ was pope, enjoying his patronage and the patronage of three of his successors. Pagninus based his dictionary, not on Sefer Aruk directly, but on a Jewish summary, the Sefer Aruk ha-Q izzur. ${ }^{24}$ Pagninus's work was reprinted twice in expanded form, once in the sixth volume of the Antwerp Polyglot (1568-72), edited by Guy le Fevre de la Boderie, and as the Thesaurus Linguae Sanctae sive Lexicon hebraicum with annotations by J ean M ercier, Cornelius B ertram and Pierre Chevalier, printed in Lyons, 1575 and reprinted in 1577.

Sebastian M iinster also wrote an A ramaic dictionary, which he had printed in 1527, the same year as his grammar. He based his work on both a manuscript copy of the Sefer Aruk ha-Qizzur, which he found in a Dominican monastery library in Regensburg, and upon Pagninus's Enchiridion ${ }^{25} \mathrm{His}$ old teacher, Pellican, also gave him his notes on Talmudic vocabulary to include in the dictionary. ${ }^{26}$ David de Pomis, a Jewish physician, composed the final Postbiblical Hebrew/A ramaic dictionary for Christians that appeared in the sixteenth century. H is Zemah David (V enice, 1587) was also based on the Sefer Aruk and provided glosses in Italian as well as Latin.

W hile L atin-language A ramaic grammars and dictionaries were essential for Christian students to learn the language, translations of A ramaic texts were an important aid to study as well. Because the Targums were valuable to Catholic, Reformed, and Lutheran theologians alike, and both the Zohar and Talmud had far fewer Christian readers, it is no surprise that only targumic texts were published in Latin translation during the sixteenth century. B ut these translated Targums appeared in two distinctly different kinds of publications, polyglot Bibles and small annotated editions, usually of single books for use as textbooks.

The earliest Targum to appear in a Christian printing with Latin translation was published as part of A gostino Giustiniani 's P salterium hebraeum, graecum, arabicum et chaldaeum (Genoa, 1516). Giustiniani provided not only the targumic text of the Psalms but also a Latin translation. The patronage of Cardinal Sauli was essential for the printing of this pioneering work, and Sauli's arrest in 1517 (as well as the poor sales of the Psalter), frustrated Giustiniani's ambition

24. Samuel K rauss provided an extensive evaluation of one manuscript of the Aruk haQizzur, which had been owned by Italian Jewish grammarian A braham de Balmes (14401523), in "A ruch ms. B reslau," M onatsschriftfur G eschichte und Wissenschaft desjudentums 73 (1929) 385-402, 451-65.

25. Joseph Perles, Beitrdge zur Geschichte der Hebrdischen und Aramdischen Studien (M unich: Thjeodor A ckermann, 1884) 20-30.

26. Karl Heinz Burmeister, Sebastian Miinster: Versuch eines biographischen Gesamtbildes (Basler B eitrage zur Geschichtswissenschaft 91; Basel: Helbing \& Lichtenhahn, 1963) 47. 
to continue the project until he had published an entire polyglot Bible. ${ }^{27}$ The two best-known polyglots, the Complutensian polyglot (1514-17) and the A ntwerp Polyglot (1568-73), were successfully completed because of their more secure patronage and funding.

The Complutensian Polyglot was the brainchild of Cardinal Jimenez de Cisneros. Cardinal Jimenez assembled a first-class team of scholars to prepare the text of the polyglot Bible, including two Jewish converts, Pablo Coronel and Alfonso de Zamora. The editors provided Targum O nqelos in A ramaic and a facing Latin translation. Cardinal J imenez spent about 50,000 gold ducats on preparing the text for printing. As Giustiniani had done with his Psalterium, Cardinal Jimenez dedicated the polyglot Bible to Pope L eo X. Unfortunately, the distribution of the Bible went far less smoothly than its printing. A lthough production of the polyglot was completed by 1517 , its distribution was not sanctioned until papal authorization was given in M arch of 1520. Of the 600 sets printed, many were lost in a shipwreck. ${ }^{28}$ It was a handsome, monumental Bible printing, whose size and distribution troubles limited its influence.

The A ntwerp Polyglot Bible was meant both to update and to surpass the older Complutensian Polyglot Bible. It was edited and produced under far different circumstances, however, from its predecessor's. While its publication was justified primarily on the basis of its usefulness to the Catholic Church and the luster that it would add to the reputation of King Philip II of Spain, it was also intended to be a philological weapon of war against Protestantism. ${ }^{29}$ In contrast to the older Complutensian Polyglot, the Antwerp Bible contained Targums to nearly every book of the Hebrew Bible, with facing Latin translation by $B$ enito $A$ rias $M$ ontano, the editor-in-chief himself. ${ }^{30}$ It also featured an A ramaic dictionary and brief grammatical sketch written by Guy le Fevre de la Boderie, one of Guillaume Postel's best students form the University of Paris.

27. R. Gerald Hobbs, "A gostino Giustiniani of Genoa," in Contemporaries of Erasmus: A Biographical Register of the Renaissance and Reformation 2 (ed. Peter G. Bietenholz and Thomas B. Deutscher; 3 vols.; Toronto: University of Toronto Press, 1985-87) 2.102-3. In 1517, Cardinal Sauli plotted with several other high-churchmen against Pope Leo $\mathbf{X}$, and his arrest on $\mathrm{M}$ ay 19, 1517 effectively ended his career in the church hierarchy. See D. S. Chambers, "B andinello Sauli, of Genoa," in Contemporaries of Erasmus, 3.198-99.

28. Erika P umme[, J imenez de Cisneros: On the Threshold of Spain's Golden Age (M edieval and R enaissance Texts and Studies 212; R enaissance $M$ asters 3; Tempe: A rizona Center for Medieval and Renaissance Studies, 1999) 58-65.

29. Leon Voet, The Golden Compasses: A History and Evaluation of the Printing and Publishing Activities of the Officina Plantiniana at Antwerp (2 vols.; A msterdam: Vangendt, 1972) $1: 63$.

30. B. Rekers, Benito Arias M ontana (1527-1598) (Studies of the W arburg Institute 33; London: The W arburg Institute / L eiden: B rill, 1972) 48. 
Volume 8 also included Franz Raphelengius's collation of variant readings in the Targums. ${ }^{31} \mathrm{~K}$ ing Philip II provided an initial subsidy of 12,000 guilders to underwrite the costs, which ultimately would grow to 21,000 guilders. ${ }^{32}$

The final Polyglot Bible to appear in the sixteenth century was the work, not of a group of well-connected Catholic scholars, but of an extraordinarily persuasive L utheran, Elias Hutter. ${ }^{33}$ Hutter can probably best be understood as an educational visionary and entrepreneur. In 1597, when he arrived in Nuremberg, Hutter planned to found a school for languages and sought the support of the city council to publish multilingual books, a monumental multilingual dictionary, a New Testament edition in twelve languages, and then his enormous Hexateuch printing in Hebrew, A ramaic, Greek, Latin, German, Slavonic, French, and Italian. To finance the printing of these complicated works, Hutter borrowed an enormous amount of money from the city council, 14,000 Gulden for the Hexateuch alone in $1600 .{ }^{34}$ Sales of Hutter's books were too slow to repay his loans to the city council, and Hutter was forced first to turn over his remaining stock of books in 1604 and then to leave town in early 1605 , never to return. ${ }^{35} \mathrm{H}$ is polyglot $\mathrm{Hexateuch}$ would be only an odd footnote in Targum studies, except that the Nuremberg city council was desperate to recoup some of their losses. They used several different strategies to sell off the remainder of Hutter's stock, and these books were fairly easy to find on the book market. ${ }^{36}$

The generosity of wealthy or powerful patrons was only one factor in the circulation of A ramaic texts. The foundation of chairs of Hebrew in northern European universities meant that the potential existed for regular A ramaic classes and therefore textbook sales. J ean Cinqarbres and J ean M ercier, both professors of Hebrew at the College Royale of Paris were among the first to print A ramaic readers for their students. ${ }^{37}$ B etween 1550 and 1562, M ercier

31. Ibid., 53.

32. V oet, The Golden Compasses, 1:61, 63 n. 2.

33. A nother $L$ utheran scholar, J ohannes D raconites, also published selections from $G$ enesis Psalms, and Isaiah and the complete books of Proverbs, J oel, M icah, Zechariah, and M alachi in a polyglot format that included Targums. The books were printed individually in W ittenberg and L eipzig between 1563 and 1565 (J ohannes Schilling, "J ohannes D rachs M arburger Gedenkrede auf Martin Luther," in Dona M elancthoniana: Festgabefiir Heinz Scheible zum 70. G eburtstag [ed. J ohanna L oehr; Stuttgart-B ad Cannstatt: F romman-H ol zboog, 2001] 391-93).

34. Lore Sporhan-K rempel and Theodor Wohnhaas, "Elias Hutter in Nurnberg und seine Biblia in etiiche Sprachen," Archivfur Geschichte des Buchwesens 27 (1986) 158-59.

35. Ibid., 160.

36. Ibid., 161.

37. The first to do so was Paul Fagius, who published a translation of Targum Onqelos in Strasbourg, 1546. BJ chard R-aubenheimer, Paul Fagius aus Rheinzabern: Sein Leben und Wirken 
prepared seven different student editions of books of the Targum, mostly the $\mathrm{M}$ inor Prophets but also the books of Proverbs and Ecclesiastes. His colleague, $J$ ean Cinqarbres, printed another three A ramaic readers with the texts of Lamentations (1549) and Hosea (1554-56). ${ }^{38}$ Other Targums for biblical books were published by Erasmus 0. Schreckenfuchs (Song of Solomon, Basel, 1553), Pierre Costus (Ecclesiastes, L yons, 1554); Gilbert Genebrard (J oel, Paris, 1563), and A rnauld Pontac (Obadiah, Jonah, Zechariah, Paris, 1566). Immanuel Tremellius published a $L$ atin translation, without the A ramaic text, of the twelve Minor Prophets (Heidelberg, 1567).

Although neither the Zohar nor the Talmud was published in Latin translation, either in part or in their entirety, during the sixteenth century, they were objects of enthusiastic study by at least some Christian scholars. ${ }^{39}$ A mong Christian students of the Zohar, Guillaume Postel stands out, because he translated the entire work into Latin and prepared it for publication. Postel first acquired a manuscript copy of the Zohar in Venice during 1547, and he began his first translation of it the following year. In addition to his considerable linguistic skills, Postel brought to the task of translation his idiosyncratic understanding of a universal salvation, which he derived from the Zohar as interpreted by the "Venetian V irgin," M other Johanna, his spiritual mentor. ${ }^{40}$ A fter the Zohar appeared in print for the first time (Cremona, 1558- 59), Postel acquired a copy of it and translated the Zohar a second time into Latin. ${ }^{41}$ He tried unsuccessfully a number of times between 1553 and 1580 to convince various $B$ asel printers to print his Zohar translation. ${ }^{42}$

als Reformator und Gelehrter (Veroffentlichungen des Vereins fur Pfalzische Kirchengeschichte 6; Griinstadt [Pfalz]: Emil Sommer, 1957) 62-65.

38. SophieK essl erM esguiche, "L 'enseignementdeF hebreu et deF arameena Paris (1530_ 1560) d'apres les oeuvres grammaticales des lecteurs royaux," in Les origins du College de F rance (1500-1560) (ed. M arc Fumaroli; Paris: College de France/K lincksieck, 1998) 366-70.

39. For literature on sixteenth-century Christian Kabbalism, see Francois Secret, Les Kabbalistes Chretiens de la Renaissance (Paris: Dunod, 1964); Gershom Scholem, Kabbalistes Chretiens (Cahiers de FHermetisme; Paris: Albin Michel, 1979). See also Giulio Bust, "Francesco Zorzi: A M ethodological Dreamer," in The Christian Kabbalah: J ewish Mystical Books and Their Christian Interpreters (ed. Joseph Dan; Cambridge: Harvard College Library, 1997) 102 and 120 n. 26.

40. Marion L. K untz, Guillaume Postel: Prophet of the Restitution of All Things. His Life and Thought (International A rchives of the History of Ideas 98; The Hague: M artinus Nijhoff, 1981) 83-84.

41. Ibid., 137.

42. Ibid., 138. See also Carlos Gilly, Spanien und die Basler Buchdruck bis 1600: Ein Querschnitt durch die spanische $G$ eistesgeschichte aus der Sicht einer europdischen Buchdruckerstadt (Basler Beitrage zur Geschichtswissenschaft 151; Frankfurt/M ain: Helbing / Basel: Lichtenhahn, 1985) 77-78. 
Talmudic study was by far the most difficult branch of A ramaic literature that a Christian could pursue. During the sixteenth century (and also the seventeenth), Christian students normally needed a Jewish tutor to make any progress at all. Wolfgang Capito owned a Talmud, but he gave it to Conrad Pellican in Zurich in 1526 because he had no tutor to help him learn. Pellican would ultimately make substantial use of Capito's gift. From 1538 to 1540, Pellican had the help of M ichael A dam, a J ewish convert, as he translated portions of the Talmud into Latin. At first the work went very slowly, because A dam knew no Latin and also could not read German. The two men spent half an hour a day reading Talmud, A dam explaining a given passage in German, while Pellican wrote down the Latin translation. ${ }^{43}$ Ultimately Pellican, with Adam's help, translated 17 tractates, drawn from both the Babylonian and the Palestinian Talmuds, all of which remained unpublished. Pellican's motive for devoting decades to the work, however, was apologetic rather than humanistic. He wrote to a colleague in 1550, "W hy should anyone devote themselves to these Jewish unworthy things? Only to prevent the Jews, who alone master it, from creating confusion among Christians." Pellican believed that combing J ewish literature for valuable information and insights was like "looking for gemstones in heaps of manure." ${ }^{44}$ Christian scholars did not begin to make serious use of the Talmud as a historical source for understanding the Bible until the early seventeenth century, when Johannes Coccejus and Constantijn L'E mpereur began their careers. ${ }^{45}$

A part from Pellican's motive of "knowing one's enemy," another use for Talmudic learning among Christians was preparing censors to read J ewish books. W hile the majority of $\mathrm{Hebrew}$ censors in I taly were J ewish converts, there were a few both in Italy and in Germany who were non-J ews. In order to gain the knowledge necessary to evaluate the Talmud at all, these Christian censors had to have instruction from J ews or J ewish converts. For example, three different men censored portions of the B asel Talmud between 1578 and 1580: Immanuel Tremellius, a J ewish convert; his former student from the U niversity of Heidelberg, Pierre Chevalier; and $M$ arius $M$ arinus, the papal inquisitor of $V$ enice. $M$ arinus had first learned Hebrew from Pablo $V$ eneto, a J ewish convert and a fellow A ugustinian monk in the Congregation of S. Salvator of B rescia. Later $M$ arinus would receive further instruction from Samuel $A$ rchevoiti in $V$ enice at the same time that young Leon M odena studied with him. ${ }^{46}$

43. Christoph Zuricher, Konrad Pellikans Wirken in Zurich, 1526-1556 (Ziircher Beitrage zur R eformationsgeschichte 4; Zurich: Theologischer V erlag, 1975) 169-74.

44. Ibid., 190-91.

45. V an Rooden, Theology, Biblical Scholarship, and Rabbinic Studies, 119-30, 179-82.

46. Fausto Parente, "The Index, The Holy Office, The Condemnation of the Talmud and Publication of Clement VIII's Index," in Church, Censorship and Culture in Early Modern 
By the 1560s, the basic philological tools for Aramaic study had been forged, and a workable rationale for studying the Targums, the Zohar, and the Talmud had been worked out. But how widespread was the study of A ramaic among sixteenth-century Christians? Was it the hobby of a very few or a more-established, intellectual pursuit? That A ramaic study was no mere hobby is clear from an analysis of the places in which Christian A ramaic books were produced and from an examination of the records of Christian libraries in which J ewish A ramaic books found a home.

While knowledge of Biblical Hebrew was not uncommon among Christian theologians of the sixteenth century, they were seldom proficient in postbiblical A ramaic. A comparison of printing statistics for $\mathrm{Hebrew}$ and A ramaic philological books written for $C$ hristians suggests different markets for each kind of book. Over the course of the century, 852 philological books on Hebrewrelated topics were printed for Christians, while only 61 were printed that contained substantial information on A ramaic. Of the books that were produced, only three of the authors, Elias Levita, Sanies Pagninus, and J ean M ercier had their works reprinted, which implies a lack of demand for the titles.

Because the demand for A ramaic books was not particularly high, patronage was essential for both the scholars who wrote them and for the printers who produced them. Some of the very earliest scholars were beholden to generous benefactors of many kinds. Elias Levita lived for more than a decade in the household of Egidio de Viterbo and was strongly encouraged not only to provide language instruction but also to publish in the fields of Hebrew and A ramaic studies. B oth $A$ gostino Giustiniani and Santes Pagninus al so enjoyed the patronage of high Catholic churchmen, in Pagninus's case the support of no fewer than four popes. Cardinal Jimenez and Agostino Giustiniani both dedicated their works to Pope Leo X. David de Pomis dedicated his Zemach David to Pope Sixtus V. The monumental polyglot Bibles would not have appeared in print at all without the help of generous patrons, a cardinal and a king, who helped to defray their production costs.

B efore we conclude that Christian A ramaism was an oddity, the pursuit of devoted hobbyists, we should remember that the true harvest in terms of Christian translation and study of these Jewish classics could only come after the dogged scholarship of J ohannes B uxtorf the Elder and $Y$ ounger produced the monumental Lexicon Chaldaicum Talmudicum et Rabbinicum (1639-40). Y et between the days of $\mathrm{M}$ iinster, Pagninus, and Buxtorf there were a sufficient number of Christians interested in A ramaic that a measurable number of $\mathrm{J}$ ewish A ramaic books began to form part of their libraries.

Italy (ed. Gigliola Fragnito; trans. A drian B elton; Cambridge: Cambridge University Press, 2001) 171-72. 
Inventories of two university and seven private libraries, dating from the sixteenth and seventeenth centuries, provide remarkable insights into the progress of A ramaic studies among Christians. ${ }^{47}$ All of the scholars, except J 0seph Scaliger, were German, as were the university library catalogs. Five of the seven libraries owned by individual scholars contained complete Babylonian Talmuds, and three also contained Palestinian Talmuds, while Reuchlin had only a manuscript copy of b. Sanhedrin. The Strasbourg University Library owned both Talmuds. Lucas Edenberger, Wittenberg University's librarian, tried to purchase a Talmud in V enice during 1541 but was deterred by its high cost. ${ }^{48}$ In 1593, J ohannes Piscator, the rector of the newly founded Herborn A cademy, solicited the gift of a Babylonian Talmud from Count Wilhelm Ludwig, Stadholder of the Dutch province of Friesland and oldest son of Count J ohann VI of Nassau-Dillenberg, for the library. ${ }^{49}$ These library lists and the wishes of Edenberger and Piscator to acquire Talmuds for their institutions all underscore its importance for Christian thinkers by 1600 .

The Targums are represented in every one of these lists in a wide variety of formats. The Biblia rabbinica, printed in $V$ eniceby D aniel B omberg, wasstrongly represented. Only Georg Siegel did not own one. M artin Bucer, Conrad Pellican, and Sebastian Miinster each owned two different printings, as did the Strasbourg library. Several leading W ittenberg scholars including M elanchthon, Caspar Cruciger, and possibly even Luther himself also owned copies of either the 1517 or $1524-25$ editions of the Biblia rabbinica. ${ }^{50}$ Each library has at least one other Targum text, whether in the form of a Pentateuch with Targum (Strasbourg, R euchlin, Scaliger), a polyglotBible (Pappus), or Giustiniani's P salterium (W ittenberg, B ucer, Pellican, Pappus, Scaliger).

The Zohar appears in only one copy in the library of J oseph Scaliger. However, it is worth remembering that kabbalistic study of any kind among Protestants and Catholics tended to be a private rather than a public or academic

47. The libraries' catalogs under discussion are the university libraries of Wittenberg (1540) and Strasbourg (1572?), and the scholarly libraries of J ohannes Reuchlin, Martin B ucer, Sebastian Miinster, Konrad Pellican, Georg Siegel, J ohannes Pappus, and Joseph Scaliger. See the appendix (pp. 434-36).

48. Ernest Schwiebert, "Remnants of a Reformation Library," Library Quarterly 10 (1940) 525.

49. Stephen G. Burnett, From Christian Hebraism to Jewish Studies: Johannes Buxtorf (1364-1629) and Hebrew Learning in the Seventeenth Century (Leiden: Brill, 1996) 6.

50. Idem, "R eassessing the 'Basel-W ittenberg Conflict,"' 187. The indistinct notation in Paul Fagius's will, written in 1549, of a "M agna biblia cum commentarijs hebraicis" from Venice should probably also be understood as a Bomberg Biblia rabbinica (E. S. LeedhamGreen, Books in Cambridge Inventories: Book-Lists from Vice-Chancellor's Court Probate Inventories in the Tudor and Stuart Periods [2 vols.; Cambridge: Cambridge U niversity Press, 1986] 1:109). 
pursuit. The number of Christian imprints of kabbalistic texts of any kind during the sixteenth century was very small, only 9 of the 912 Hebraica books. ${ }^{51}$ Even among J ews the Zohar was not widely available until after it appeared for the first time in print in Cremona in 1558- 59. Guillaume Postel, Francesco Zorzi (both living in Italy), and other Christian $\mathrm{K}$ abbalists were able to find copies of the Zohar to read before it appeared in print, but its diffusion and study among Christian Hebraists was slower than the Talmud or the Targums. ${ }^{52}$

These reflections on the Aramaic holdings of a group of predominantly German Protestant Hebraists illustrate one other trend in A ramaic scholarship. These books, which were sponsored and produced in Catholic Europe, found avid readers among Protestants. Because of its large number of universities with professors of Hebrew, Germany formed one of the largest markets for Hebrew textbooks, reference books, and for source collections such as the Biblia rabbinica. ${ }^{53}$ In the seventeenth century, Protestants scholars would take the lead in A ramaic scholarship, but even before this happened they were avid consumers of it.

Christian A ramaism, then, was born in late-fifteenth-century Italy and Spain and grew up north of the Alps during the early years of the Reformation. In its early stages it was influenced more by patronage and J ewish assistance than by the tensions of the Reformation. By the end of the sixteenth century, Christian scholars had formulated rationales for studying J ewish literature and had forged a rudimentary apparatus. They had begun the process of translating and excerpting it, especially portions of the Targums, to integrate the information they found into a Christian framework. Taken together, the growth of Christian A ramaism was a remarkable scholarly achievement.

Appendix:

Aramaic Books of Sixteenth-Century Libraries

I. University Libraries

Wittenberg University Library, $1540^{54}$

Biblia rabbinica (Bomberg, 1524-25)

Giustiniani, A gostino, P salterium (Genoa, 1516)

$M$ iinster, Dictionarium Chaldaicum (2 copies)

51. Burnett, "Christian Hebrew Printing," 21.

52. B ust, "Francesco Zorzi," 102.

53. Burnett, "Christian Hebrew Printing," 32-34.

54. Sachiko Kusukawa, A Wittenberg University Library Catalogue of 1336 (Binghamton, N.Y : M edieval and Renaissance Texts and Studies, 1995) 1-3. 
M inister, G rammaticum Chaldaicum

Strasbourg U niversity Library, [1572? $]^{55}$

Pentateuchus cum Targume corn: R. Sal \& R. Chiskum

Biblia in 2 tomis cum Targum \& Peruschim R. Sal: \& A benezrae

Biblia in 2 tomis cum Targum \& Com R. D. K. Perisol, Rav V enaki

L evita, M eturgeman

A ruch autore R. Nathan Bar Jehiel

Thalmud lerusolymitanum tribus tomis

Thalmud Babylonieum quinque tomis

II. Scholars' Libraries

Reuchlin, Johann $(1455-1522)^{56}$

B. Sanhedrin (MS)

Biblia rabbinica (Bomberg, 1517)

Pentateuch with Tg. Onqelos (B ologna, 1482)

Prophets of Targum J onathan (MS)

Bucer, M artin (1491-1551) [R. Gerald Hobbs, personal communication]

Biblia rabbinica (1517)

Biblia rabbinica (1524-25)

Giustiniani, A gostino. P salterium (Genoa, 1516; quotations from it)

M iinster, Sebastian (1488-1552) [B urmeister, M unster, 200-201]

Babylonian Talmud

Biblia rabbinica (1517)

Biblia rabbinica (1524-25)

Pagninus, Enchiridion

PeU ican, K onrad (1478-1556) [Zuricher, Konrad Pellikans Wirken, 231-36]

Babylonian Talmud

Palestinian Talmud

Biblia rabbinica (1524-25)

Biblia rabbinica (1548)

Giustiniani, A gostino. Psalterium (Genoa, 1516)

Siegel, Georg (donated to A Itdorf UB in 1598) [Eriangen UB M S 2436,

ft. 81r-83v] Theology Professor at the University of Altdorf

Basel Talmud

55. J ohannes Pappus wrote the catalog in the flyleaves of his copy of M eturgemann: Lexicon Chaidaicum Authore Eliia Levita (Isny: Fagius, 1541), Wolfenbiittel, HAB Sig. 205.1 Th. 20 (2). Professor A dam Shear of the University of Pittsburgh discovered this manuscript catalog and kindly informed me of it.

56. Karl Christ, Die Bibliothek Reuchlins in P forzheim (Leipzig: Harrassowitz, 1924; repr., Nendein, Liechtenstein: K raus Reprint, 1968) 36-51. 
Hutter, Biblia Sacra, Ebraice, Chaldaice, Craece

Targum Chaldaicum

Pappus, J ohannes (1549-1610) [Herzog A ugust B ibliothek, MS 42 A ug. 20]

Taught Hebrew at Strasbourg U niversity, 1569-75

Antwerp Polyglot

Babylonian Talmud (Basel)

Biblia rabbinica

Ambrosius, Introductio in Linguam Chaldaicam Syriacam et Armenicam \& etc.

Bertram, Crammaticae Hebraicae et Aramaicae comparatio

Giustiniani, A gostino, Psalterium (Genoa, 1516)

Hutter, Biblia Sacra, Ebraice, Chaldaice, Graece

Levita, M eturgeman (Isny, 1541)

Miinster, Dictionarium Chaldaicum

Miinster, Grammatica Chaldaica

Pagninus, Thesaurus Lingua Hebraica opera Joh. Merceri (Lyons:

Vincentium, 1575)

Schreckenfuchs, Cantica canticorum et Ecclesiastes Salomonis paraphrasticos [1553]

Thargum 0 nckeli, J onathan ben U zielis et Hierosolymitanum (in fol)

Tremellius, Grammatica Chaldaea et Syra

Scaliger, J oseph J uste (1540-1609) ${ }^{57}$

Professor at Leiden U niversity

Babylonian Talmud

Jerusalem Talmud (MS)

Biblia rabbinica (Bomberg, 1524-25)

Pentateuch with Targum and Commentries of Rashi and Rambam (?)

Pentateuch with Targum Onqelos

A mbrosius, Introductio

Caninius, Angel, Institutiones linguae Syriacae Assyriacae atque Talmudicae

Giustiniani, A gostino, Psalterium (G enoa, 1516)

Levita, M eturgeman

Mercier, Tabulae in Chaldaeam grammaticen (Paris)

Mercier (ed.), Chaldaea interpretatio sex prophetarum Hoseae, loelis,

Amos \&-etc. (1559)

Pomis, David de, Dictionarium

Zora [Zohar] (Cremona)

57. Catalogus Bibliothecae Publicae Lugduno-Batavae (Leiden: Elsevir, 1636) 159-63. 